The following paper was presented at The 9th Workshop on Disfluency in Spontaneous Speech (DiSS 2019) held at ELTE Eötvös Loránd University in Budapest, Hungary on 12-13 September, 2019.

Title: $\quad$ Error type disfluencies in consecutively interpreted and spontaneous monolingual Hungarian speech

Author(s): $\quad$ Maria Bakti

Abstract: $\quad$ Interpreting can be considered as a form of spontaneous speech, the key differences being that language change is involved in interpreting and the fact that speech production is influenced by several constraints during interpreting. Research has shown that the interpreting task influences the disfluency patterns of target language texts. The aim of this paper is to investigate how the frequency and distribution of error type disfluencies changes in the target language output of trainee interpreters as they progress in their training. Results indicate that there is no considerable change in the frequency and proportion of error type disfluencies in the target language texts recorded at the end of the second, third and fourth semesters of interpreter training. The proportion of error type disfluencies is higher in the consecutively interpreted texts than in the spontaneous monolingual speech of the students. This suggests that the complexity of the task, rather than progress in training, determines the disfluency pattern of consecutively interpreted target language texts.

DOI: $\quad$ https://doi.org/10.21862/diss-09-019-bakti

Citation (JIPA): Bakti, Maria. 2019. Error type disfluencies in consecutively interpreted and spontaneous monolingual Hungarian speech. In: R. L. Rose \& R. Eklund (eds.), Proceedings of DiSS 2019, The 9th Workshop on Disfluency in Spontaneous Speech, 12-13 September, 2019, Budapest, Hungary, 71-74.

The complete proceedings for DiSS 2019 are available as follows.

ISBN: $\quad$ 978-963-489-063-8

DOI: $\quad$ https://doi.org/10.21862/diss-09

DiSS 2019 was sponsored by The Faculty of Humanities, ELTE Eötvös Loránd University and the International Speech Communication Association (ISCA).
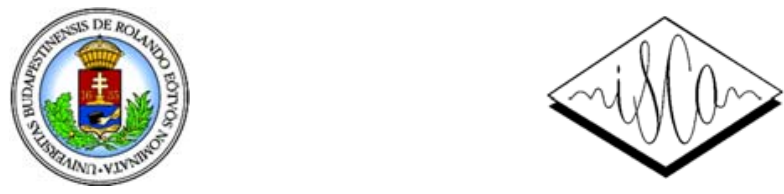


\title{
Error type disfluencies in consecutively interpreted and spontaneous monolingual Hungarian speech
}

\author{
Maria Bakti \\ Department of Modern Languages and Cultures, University of Szeged, Szeged, Hungary
}

\begin{abstract}
Interpreting can be considered as a form of spontaneous speech, the key differences being that language change is involved in interpreting and the fact that speech production is influenced by several constraints during interpreting. Research has shown that the interpreting task influences the disfluency patterns of target language texts. The aim of this paper is to investigate how the frequency and distribution of error type disfluencies changes in the target language output of trainee interpreters as they progress in their training. Results indicate that there is no considerable change in the frequency and proportion of error type disfluencies in the target language texts recorded at the end of the second, third and fourth semesters of interpreter training. The proportion of error type disfluencies is higher in the consecutively interpreted texts than in the spontaneous monolingual speech of the students. This suggests that the complexity of the task, rather than progress in training, determines the disfluency pattern of consecutively interpreted target language texts.
\end{abstract}

\section{Introduction}

Speech production during interpreting has received considerable research attention to date. Simultaneous Interpreting (SI) can be considered as a variety of spontaneous speech (Goldman-Eisler, 1968); Kopczyński concurs with this view, highlighting that the target language (TL) text produced by an interpreter is "produced on the spot, on the basis of a previously unknown text" (Kopczyński, 1982: 257). This TL text is produced under time pressure and other cognitive constraints, and thus it can be expected to be prone to speech errors (Bakti, 2015: 368). Interpreters render a source language (SL) message in the TL, in other words they reproduce the ideas of the SL speaker instead of their own. In addition, they work based on an incomplete SL input.

Studies on fluency and pauses in interpreting have mostly focused on the simultaneous mode and include work on pauses (Tissi, 2000) and self-repairs (Petite, 2005). The analysis of error type disfluencies (ETDs) in simultaneously interpreted Hungarian TL texts showed that restarts, grammar errors and false words had the highest proportion in the TL output of interpreters, (Bakti, 2009) and the frequency of ETDs (ETDs/100 words) was between 2.8 and 6.2 in the case of trainee interpreters (Bakti, 2013).

However, the psycholinguistic aspects of Consecutive Interpreting (CI) have received limited research attention to date. CI comprises of two stages; the first is listening and note taking, during which active analysis takes place, followed by the production and note-reading stage. During this second stage, interpreters produce a target language text based on their memory and their notes, which can be either language dependent or may comprise of language-independent symbols, or both.

The basic tenets of Gile's Effort Models in interpretation are that interpretation requires mental energy that is available in limited supply, and that interpretation takes up almost all of this mental energy (Gile, 1995: 161). In CI, mental energy is used for the following Efforts during the listening and note-taking phase: listening and analysis, notetaking, short-term memory operations, and coordination. During the production phase, the following efforts require mental energy: remembering, note-reading, and production (Gile, 1995: 179). As competence develops during training, trainee interpreters learn how to best use their mental energy or attentional resources in order to produce high quality TL texts during CI. During this process of expert skill acquisition, some of the processes involved in CI become automatic (Albl-Mikasa, 2013).

Mead examined the control of pauses by trainee and professional interpreters in their A (L1) and B (L2) languages in CI (Mead, 2000, 2002) and found that the proportion of pauses was higher in the output of trainee interpreters when they were interpreting into their B language. In his second investigation Mead found that with the increase in interpreting experience, the proportion of hesitations related to grammatical and lexical problems decreased. Bakti and Bóna (2017) compared the disfluency patterns of spontaneous, semi-spontaneous, consecutively interpreted and sight translated texts. They have found that disfluencies are a function of the interpreting task; this finding is based on a crosssectional study.

The aim of this paper is to investigate error-type disfluencies in consecutively interpreted Hungarian 
TL texts that were recorded in the framework of a longitudinal study with the aim to compare the proportion and frequency of the occurrence of ETDs in the TL texts recorded at different stages of a Master's Program in interpreting. In addition, figures are compared to the Hungarian monolingual spontaneous (i.e. not interpreted) speech of the participants.

This paper aims to answer the following research questions:

1. What is the proportion of ETDs in the consecutively interpreted (English to Hungarian) TL output of trainee interpreters recorded at different stages of their MA training?

2. How does the proportion of ETDs in interpreted texts differs from the proportion of ETDs in the spontaneous Hungarian monolingual speech of the students?

3. What are the most frequent disfluencies in the interpreted texts and how do they change as students progress in training?

Based on the literature I worked with the following hypotheses:

1. The proportion of ETDs will decrease in the interpreted texts as training progresses, because students will gain expertise and their TL speech production will become more fluent.

2. There will be more ETDs in the interpreted texts than in the spontaneous monolingual speech of the trainee interpreters, as speech production during $\mathrm{CI}$ is more complex than spontaneous monolingual speech production.

3. Even though students progress in training and gain expertise in interpreting, there will be no changes in the disfluency pattern of the TL consecutively interpreted texts, as disfluency patterns are task-specific.

\section{Procedure}

Five female and two male MA students of interpreting participated in the longitudinal study. Participation in the study was voluntary. Recordings were made of the students' consecutive interpreting, sight translation, spontaneous and semi-spontaneous speech production. The students' mean age was 23.3 years at the end of the second semester of their studies, when the first recordings were made. These were followed by recordings at the end of the $3 \mathrm{rd}$ and 4th semesters. The Hungarian monolingual spontaneous speech samples were recorded at the end of the 2nd semester. The A language or L1 of the students is Hungarian, their B language or active language is English (for 3 students) and Spanish (4 students). The $\mathrm{C}$ or passive language of the students was English (4 students), Italian (1 student), German (1), and French (1).

Even though English was B language for 3 students and $\mathrm{C}$ language for 4 students, their English background knowledge can be considered similar; students with English as their B language had been learning English for 14.3 years when the first recordings were made, and students with English as their $\mathrm{C}$ language had been learning English for 16 years at the time when the first recordings were made.

During the CI tasks at the end of the 2nd, 3rd and 4th semesters of their studies, students interpreted English source language texts of comparable length and lexical and syntactical complexity into Hungarian. No SL texts were re-used. All three SL texts were about similar topics: introducing an institution of higher education to prospective students. For further details of the SL texts, see Table 1.

Table 1. Source Language texts for the CI tasks.

\begin{tabular}{|l|c|c|c|}
\cline { 2 - 4 } \multicolumn{1}{l|}{} & Semester 2 & Semester 3 & Semester 4 \\
\hline \hline Topic & $\begin{array}{l}\text { Williams } \\
\text { College }\end{array}$ & $\begin{array}{c}\text { Oxford } \\
\text { University }\end{array}$ & $\begin{array}{c}\text { Swansea } \\
\text { University }\end{array}$ \\
\hline $\begin{array}{l}\text { Number of words } \\
\text { SL }\end{array}$ & 492 & 477 & 511 \\
\hline $\begin{array}{l}\text { Average number of } \\
\text { words TL texts }\end{array}$ & 486.6 & 421.4 & 453.6 \\
\hline No. of sections & 10 & 10 & 10 \\
\hline
\end{tabular}

Some deviations from standard interpreting practice have to be noted. The recordings were made in a language laboratory without an audience present. These limitations undermine to some extent the ecological validity of the investigation.

The TL texts and the Hungarian monolingual spontaneous texts were transcribed and ETDs were identified in the texts, using the taxonomy of Gósy et al. (2009). The category of restarts was also added. Even though this category is a rather controversial one (Gyarmathy, 2015), as it can be seen both as an error or a disfluency rooted in uncertainty, it was included in the analysis to make it possible to compare the results with those of earlier investigations (Bakti, 2009). See Table 2 for the definitions and examples.

\section{Results}

First, the frequency of the occurrence of the ETDs was calculated. Results are shown in Table 3. The number of ETDs / 100 words of the target texts in consecutively interpreted texts show no considerable change in the course of the training. The frequency 
Table 2. ETDs examined with definitions and examples.

\begin{tabular}{|c|c|c|}
\hline ETD & Definition (Gósy et al., 2009; Gyarmathy, 2015) & $\begin{array}{l}\text { Example from the Hungarian TL texts } \\
\text { (student, semester) }\end{array}$ \\
\hline fasle word & $\begin{array}{l}\text { instead of the appropriate word, there is a different } \\
\text { word in the surface structure }\end{array}$ & írták át vagy rajzolták át (WW4) \\
\hline grammar error & $\begin{array}{l}\text { a morphological or syntactical structure that is } \\
\text { inconsistent with the norm }\end{array}$ & amely walesi Swanseaban található (E4) \\
\hline blend & blend of two signs (word, phrase) & $\begin{array}{l}\text { most pedig anélkül, hogy, a teljesség igénye } \\
\text { nélkül (S4) }\end{array}$ \\
\hline false start & $\begin{array}{l}\text { articulation of a sound or string of speech sounds } \\
\text { which do not constitute a word }\end{array}$ & $\begin{array}{l}\text { lehetőségük van a diákoknak els_tanulni } \\
\text { (L4) }\end{array}$ \\
\hline TOT & $\begin{array}{l}\text { knowledge of the morphology of the intended word, } \\
\text { inhibition of the articulation of the phonetic structure }\end{array}$ & \begin{tabular}{|l} 
gazdasággal összefüggő, gazdasággal \\
összefüggésben programokra (WW4)
\end{tabular} \\
\hline ordering problems & perseveration, anticipation, metathesis & téz évben, tíz évben (E2) \\
\hline slip & $\begin{array}{l}\text { error in articulation, adding, replacing or deleting } \\
\text { speech sounds }\end{array}$ & matekailag, matematikailag (E2) \\
\hline restart & pronunciation of the activated and partly uttered word & lássunk néhány_néhányat (WW4) \\
\hline multiple cause & $\begin{array}{l}\text { errors that fit into more than one of the above } \\
\text { categories }\end{array}$ & $\begin{array}{l}\text { müködik a az oktatás (M4) } \\
\text { This could be seen both as a restart or a } \\
\text { corrected grammar error. }\end{array}$ \\
\hline
\end{tabular}

Table 3. The frequency of ETDs in the output of trainee interpreters.

\begin{tabular}{|l|l|l|l|l}
\cline { 2 - 5 } \multicolumn{1}{l|}{} & 2nd semester & 3rd semester & 4 th semester & spontaneous speech \\
\hline \hline ETDs / 100 words & 2.17 & 2.44 & 2.45 & 1.23 \\
\hline maximum & 3.75 (Student L) & 3.48 (Student E) & 3.18 (Student Mi) & 1.95 (Student Mi) \\
\hline minimum & 1.1 (Student S) & 1.96 (Student Mi) & 1.75 (Student E) & 0.6 (Student WW) \\
\hline standard deviation & 0.879 & 0.548 & 0.515 & 0.507 \\
\hline
\end{tabular}

of ETDs in the spontaneous monolingual speech of the students is lower than in the interpreted texts, illustrating that spontaneous speech production is less complex than the concurrent tasks of consecutive interpreting.

These averages however, hide considerable individual differences. At the end of the 2nd semester, Student L had 3.75 ETDs / 100 words, and the Student S had the lowest frequency of occurrence of ETDs: 1.1 ETDs / 100 words. At the end of the third semester, Student E had 3.48 ETDs / 100 words, and Student Mi 1.96. At the end of the 4th semester Student Mi had 3.18 ETDs / 100 words, and Student E 1.75. In spontaneous speech, the lowest figure was 0.6 ETDs / 100 words, and the highest 1.95 ETDs / 100 words.

Second, the proportion of ETDs was calculated.

The results are shown in Figure 1. In the 2nd and 4th semester CI tasks, the proportion of grammar errors was the highest. In the 2nd semester, this was followed by the categories of false word and restarts. In the recordings made after the 3rd semester, the proportion of multiple cause ETDs was highest, followed by grammar errors, restarts ranked third, followed by false words. In the recordings made after the 4th semester, the category of false words followed grammar errors, and restarts ranked third. In the spontaneous monolingual speech production of the students, grammar errors and restarts had the same proportion, followed by false starts.

\section{Summary}

In summary it can be stated that the examined ETDs were more frequent in the consecutively interpreted Hungarian texts than in the spontaneous monolingual Hungarian speech of the trainees. This supports the finding of Bakti and Bóna (2017) in that the complexity of the CI task is mirrored in the disfluencies; the more complex the task, the more frequent the disfluencies are.

The results show that the average frequency of ETDs does not change considerably as students progress in their training, however, considerable individual differences exist. This finding does not confirm the first hypothesis.

The second hypothesis, that there would be more ETDs in the interpreted than in the spontaneous monolingual speech of the students, was confirmed by the data. 


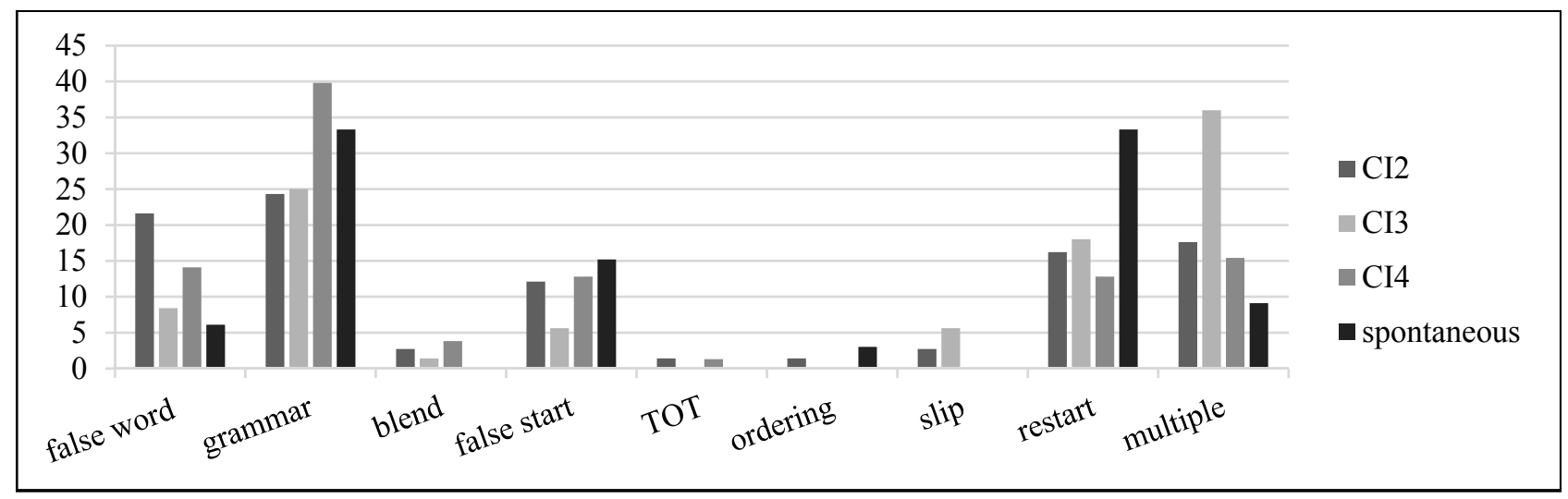

Figure 1. The proportion of ETDS in the output of trainee interpreters.

The distribution of ETDs was similar in the consecutively interpreted TL texts, which supports the third hypothesis.

Limitations of this investigation should also be noted, namely the small number of participants. The results should be tested against larger corpora.

\section{References}

Albl-Mikasa, M. 2013. Developing and cultivating expert interpreter competence. The Interpreters' Newsletter 18: 17-34.

Bakti, M. 2009. Speech Disfluencies in Simultaneous Interpreting. In: D. De Crom (ed.) Selected Papers of the CETRA Research Seminar in Translation Studies 2008, https://www.arts.kuleuven.be/cetra/papers/files/ bakti.pdf. Published online by CETRA, KU Leuven, 2009.

Bakti, M. 2013. Théorie du sens revisited. CLI in the target language output of simultaneous interpreters. In: B. Lewandowska-Tomaszczyk \& M. Thelen (eds.) Translation and Meaning Part 10, 363-370. Maastricht: Zuyd University of Applied Sciences.

Bakti, M. 2015. Slips. In: F. Pöchhacker (ed.) The Routledge Encyclopedia of Interpreting Studies, 386387. New York, London: Routledge.

Bakti, M. \& J. Bóna. 2017. A contrastive analysis of disfluency markers in four different settings. Conference poster: Fluency and Disfluency Across Languages and Language Varieties Conference, Université Catholique de Louvain, Louvain-le-Neuve, Belgium, February 2017.
Gyarmathy, D. 2015. Diszharmóniás jelenségek, megakadások a beszédben [Disharmonies and speech disfluencies]. In: M. Gósy (ed.) Diszharmóniás jelenségek a beszédben [Disharmonic phenomena in speech], 9-47. Budapest: MTA Nyelvtudományi Intézet.

Gile, D. 1995. Basic Concepts and Models for Interpreter and Translator Training. Amsterdam: John Benjamins. https://doi.org/10.1075/btl.8(1st)

Goldman-Eisler, F. 1968. Psycholinguistics; experiments in spontaneous speech. London, UK: Academic Press.

Gósy M., J. Bóna, T. Gráczy, V. Horváth, A. Imre, \& T. Neuberger. 2009. Nyelvbotlás korpusz, 6. Rész [Speech Error Corpus, Part 6]. Beszédkutatás 2009: 257-267.

Kopczyński, A. 1982. Effects of some characteristics of impromptu speech on conference interpreting. In: N. Enkvist (ed.) Impromptu Speech: A Symposium., 255-266. Abo: Abo Akademie.

Mead, P. 2000. Control of pauses by trainee interpreters in their A and B languages. The Interpreters' Newsletter $10,89-102$.

Mead, P. 2002. Exploring hesitation in consecutive interpreting: An empirical study. In: G. Garzone \& M. Viezzi (eds.), Interpreting in the 21st Century. Challenges and Opportunities, 73-82 Amsterdam: John Benjamins. https://doi.org/10.1075/btl.43.08mea

Petite, C. 2005. Evidence of repair mechanisms in simultaneous interpreting: A corpus-based analysis. Interpreting 7(1): 27-49. https://doi.org/10.1075/intp.7.1.03pet

Tissi, B. 2000. Silent pauses and disfluencies in simultaneous interpretation: A descriptive analysis. The Interpreters' Newsletter 10, 103-127. 